\title{
Sacramentum Pacis: The Eucharist as the Sacrament of Peace
}

\author{
John A. Monaco \\ Boston College School of Theology and Ministry (Brighton, MA)
}

\begin{abstract}
This paper will examine the nature of the Eucharist as a "sacrament of peace", a sacrament by which the Christian believer is reconciled to Christ and the Church. While, properly-speaking, the Sacrament of Reconciliation is the ordinary means of this activity, one sees that the Eucharist provides a healing balm for sin, enflames the soul with the fire of charity, and reveals itself as both a symbol of peace already realized and a sign of peace yet to come. This "sacrament of peace" bestows God's peace to the Church, which, in turn, commissions the Christian to embody this peace through works of mercy and initiatives of justice. Through this, we see the social and missional implications for a community centered around the Eucharistic table. Helpful to this investigation will be the Eucharistic theology of the late Orthodox theologian, Alexander Schmemann and Pope Emeritus Benedict XVI.
\end{abstract}

\section{Text}

\section{Introduction}

The sacrifice of Christ on Calvary is undoubtedly an integral part of Christianity, and its re-presentation on the altars of our churches, as the Church proclaims in Lumen gentium, is indeed the "fount and apex of the whole Christian life." Popular piety and spiritual writers often describe the Eucharist as a "sacrament of love," in which Christ demonstrates the loving kindness of the Godhead through his passion, death, and Resurrection. While this is certainly true, a world wounded by sin and division desires to see this divine love, present in the holy sacrament, actualized in concrete ways in the lives of the Christian faithful. In other words, if the Christian

\footnotetext{
${ }^{1}$ Vatican Council, Dogmatic Constitution on the Church: Lumen gentium, solemnly promulgated by His Holiness, Pope Paul VI on November 21, 1964, 11, at The Holy See, accessed October 4, 2017. http://www.vatican.va/archive/hist_councils/ii_vatican_council/documents/vat-ii_con st_19641121_lumen-gentium_en.html, 11.
} 
sees the Eucharist as merely a sight to behold rather than a call of love to be lived out, the fruits of Christ's paschal mystery will not reach the larger global community.

This paper will examine the nature of the Eucharist as sacramentum pacisa "sacrament of peace" - a sacrament by which the Christian believer is reconciled to Christ and the Church. The peace the Eucharist offers is not simply an absence of conflict, but rather an active peace, one that works towards the reconciliation and healing of persons. While, properly speaking, the sacrament of reconciliation is the ordinary means of this activity, ${ }^{2}$ one sees that the Eucharist provides a healing balm for sin, enflames the soul with the fire of charity, and reveals itself as both a symbol of peace already realized and a sign of peace yet to come. This "sacrament of peace" bestows God's peace to the Church, which, in turn, commissions the Christian to embody this peace through works of mercy and initiatives of justice. Through this, we see the social and missional implications for a community centered around the Eucharistic table. Helpful to this investigation will be the Eucharistic theology of the late Orthodox theologian, Alexander Schmemann and Pope Emeritus Benedict XVI.

As mentioned previously, the term sacramentum pacis seems more applicable to the sacrament of reconciliation, whereby the Christian obtains pardon for his or her sins and is reconciled to the Church. ${ }^{3}$ While this is certainly true, the Eucharist also has the effect of forgiveness of venial sins. The Catechism of the Catholic Church, citing the Council of Trent, explains how the Eucharist "strengthens our charity, which tends to be weakened in daily life; and this living charity wipes away venial sins." 4 In addition to the pardon received, the Eucharist also bestows peace. As St. Thomas Aquinas points out, peace is the proper effect of charity. ${ }^{5}$ While the scope of the sacrament of reconciliation should be respected (as it is the necessary and ordinary means for the forgiveness of mortal sins), the Christian should be aware of the healing power of the Eucharist. The Eucharist can be spoken of as a "sacrament of peace" in two main ways: first, because it is the sacrament by which humankind is reconciled to God; and second, because it is the sacrament by which humankind is reconciled to one another.

${ }^{2}$ Catechism of the Catholic Church, 2nd ed. (Washington, DC: United States Catholic Conference, 2000), 1497.

${ }^{3}$ Lumen gentium, 11.

${ }^{4}$ Catechism of the Catholic Church, 1394.

${ }^{5}$ Thomas Aquinas, Summa Theologica, II-II, q. 29, a. 3, resp.; in the Summa Theologiae of St. Thomas Aquinas, Second and Revised Edition, 1920, Fathers of the English Dominican Province, Online Edition, ed. Kevin Knight, New Advent, accessed October 4, 2017, http://www.newadvent.org/summa/3029.htm. 


\section{Peace: Humankind to God}

What does the Eucharist $d o$ ? For centuries, this has been the question that sacramental theologians asked. Neo-Scholasticism fixated upon questions of matter and form, substance and accidents; and while these distinctions can provide help for explaining the Eucharistic 'change' in detail, what arguably is lost is the focus on the liturgy (the leitourgia), the "divine service" God performs on behalf of God's people. The story of the liturgy is the story of salvation, because it is in the liturgy that the Christian participates in Christ's saving paschal mystery. In essence, the liturgy is pure gift, given by the giver of all good gifts (James 1:17, NIV). As an "action of the whole Christ (Christus totus)," the liturgy we celebrate here on earth is the same liturgy present in heaven, attended by the saints and angels. The main celebrant, Christ, pours out upon his Church the fruits of his paschal mystery which we celebrate here on earth through signs and symbols.

Instead of asking what the Eucharist does we should ask what the Eucharist is. Put simply, the Eucharist is the sacrament of Christ's passion, death, and resurrection, whereby the recipient receives Christ's body, blood, soul, and divinity. Christ is truly, wholly, and substantially present under the sacramental species of what appears to the human senses as bread and wine. The Eucharist is conferred through the context of the Holy Sacrifice of the Mass, the re-presentation of Christ's once-and-for-all sacrifice to the Father on behalf of humankind. The "source and summit of the Christian life,"7 the Eucharist enjoys the privilege of being the way the Christian most intimately partakes in the divine life here on earth.

The peace bestowed through the Eucharist is the peace that bridges the gap between the human and divine, a gap originating in the Fall of Adam and Eve. In his book, For the Life of the World, Alexander Schmemann writes that "The only real fall of man is in his non-eucharistic life in a non-eucharistic world." 8 According to Schmemann, because the human vocation was to bless God in the world in thanksgiving, the 'falling out' of communion with God is rooted in a thanklessness, a presumption of pride by which we do not realize our radical dependency on God. Ultimately, the Fall was humanity's rejection of friendship with God, resulting in a lack of true peace. The Hebrew Scriptures demonstrate how God continued to extend the offer of friendship, preparing Israel for the coming of Christ. God's peace (shalom) became Incarnate in the "Prince of Peace" (Isa. 9:6). Through his ministry, Christ blessed the peacemakers (Matt. 5:9); through his cross, he 'made' peace between God and humanity (Col. 1:20). As the re-presentation of Christ's

${ }^{6}$ Catechism of the Catholic Church, 2nd ed. (Washington, DC: United States Catholic Conference, 2000), 1136.

${ }^{7}$ Catechism of the Catholic Church, 1324.

8 Alexander Schmemann, For The Life of the World (Crestwood, NY: St. Vladimir's Seminary Press, 2004), 19-20. 
sacrifice on Calvary, the Eucharist perpetuates the work of the Son in achieving our redemption and salvation. The Eucharist, then, can be spoken of as "a sacrament of peace" precisely because it is the memorial of Christ's saving act. As prefigured in the Hebrew Scriptures through God's covenant with Israel and Israel's sacrificial worship, the Eucharist is the efficacious sign of Christ's kingdom. ${ }^{9}$ Schmemann sees the Eucharistic sacrifice as the place where we now "offer to God the totality of all our lives, of ourselves, of the world in which we live." 10 Schmemann's theology follows a familiar exitus-reditus (exit and return) theme present through the tradition. The classic dictum, "God became human so that humans may become God"11 is itself Eucharistic: the offering of Christ to the Father is the remedy to our estrangement from God's friendship, and so, we too unite ourselves to Christ's sacrifice when we participate in the Sacred Liturgy. In a sense, we become divinized by the Eucharist, restoring us to 'right-relationship' with God. It is helpful, then, to not replace the term "Holy Sacrifice of the Mass" exclusively with "Celebration of the Eucharist." As Peter Kwasniewski points out, "Since our Lord's sacrifice on the Cross is the Alpha and Omega of the Christian economy, the Eucharistic sacrifice is the focal point of cosmic reality, in relation to which every intellectual creature stands. Every angel and every man stands in some relationship, whether of salvation or of condemnation, to the 'bread of angels', Jesus Christ in his flesh and blood."'12

\section{Humankind to One Another}

The Eucharist is not simply a reconciliation between God and humanity, but also extends on a horizontal plane - it effects a reconciliation between humans with one another. Gathered around the Eucharistic table, the rich and poor, the young and old, the healthy and sick all are nourished and transformed by Christ's Body and Blood. Even in the act of gathering, reconciliation takes place. In his First Letter to the Corinthians, we hear Paul condemning the practice of the "love feasts" which tended to exclude the hungry and poor; it is for this reason that Paul bluntly tells the community that such exclusive gatherings are not the Lord's Supper (1 Cor. 11:20-21). Central to Paul's Eucharistic theology is the social dimension of the Body of Christ. It is telling that his handing on of the words of institution (1 Cor. 11:23) come only after he criticizes the community at Corinth for desecrating the Eucharistic celebration with their exclusive, drunken feasts. Elsewhere, we see the

${ }^{9}$ Schmemann, 28.

${ }^{10}$ Schmemann, 40.

${ }^{11}$ Athanasius of Alexandria, De Incarnatione verbi, 54, 3, trans. Archibald Robertson, in Nicene and Post-Nicene Fathers, Second Series, Vol. 4, ed. Philip Schaff and Henry Wace (Buffalo, NY: Christian Literature Publishing Co., 1892), ed. by Kevin Knight, New Advent, accessed October 4, 2017, http://www.newadvent.org/fathers/2802.htm.

${ }_{12}$ Peter A Kwasniewski, Resurgent in the Midst of Crisis (Tacoma, WA: Angelico Press, 2015), 150 . 
unifying effect of the Body of Christ. As Paul's Letter to the Galatians shows, deep societal divisions in the first century - such as those of slaves and free men, Greeks and barbarians, Jews and Gentiles (Gal. 3:28)—were to be healed by the one person of Christ. ${ }^{13}$

Certainly, such divisions extend even in contemporary times. One can see, however, that following the Second Vatican Council, Eucharistic theology took on the task of incorporating the "social dimension" of the Eucharist in the discussion that followed the council. For example, the 1976 Eucharistic Congress in Philadelphia had as its theme the essential link between the Eucharist and the hungers of the human family. ${ }^{14}$ Following the tragic Vietnam War and ongoing Cold War conflict, then-Cardinal Joseph Ratzinger, in a 1978 homily, suggested that in the early Church, the Eucharist was "often simply referred to as 'peace': it was the place of the presence of Jesus Christ and was thereby the sphere of a new peace... [which] transcended all boundaries and limits, in which everyone was at home everywhere."15

Pedro Arrupe, Superior General of the Society of Jesus and champion for peace and justice initiatives, wrote in 1980:

"In the Eucharist... we receive not only Christ, the Head of the Body, but [the Body's] members as well... Wherever there is suffering in the Body, wherever members of it are in want or oppressed, we, because we have received the same Body and are part of it, must be directly involved. We cannot properly receive the Bread of Life without sharing bread for life with those in want."16

Since Christ is present in both the sacramental species as well as in the baptized members of His Body, one can understand the connection between the Body of Christ on the altar and the Body of Christ present in the suffering faithful, including those on the streets of our poorest cities.

\section{Conclusion}

So far in this paper, we have discussed the ways in which the Eucharist establishes peace between God and humanity, as well as serves as a sign of peaceful unity across societal divisions. These two effects of the Eucharist flow from the one

\footnotetext{
${ }^{13}$ c.f. Joseph Ratzinger, God Is Near Us (San Francisco, CA: Ignatius Press, 2003), 117.

${ }^{14}$ c.f. Alcuin Reid, From Eucharistic Adoration to Evangelization (Bloomsbury Publishing, London, 2012), 173.

${ }^{15}$ Ratzinger, God Is Near Us, 118.

${ }^{16}$ Pedro Arrupe, "The Eucharist and Hunger," Justice with Faith Today: Selected Letters and Addresses - II, ed. Jerome Aixala (St. Louis, MO: The Institute of Jesuit Sources, 1980), 176177.
} 
cause - namely, Christ. To close this paper, I wish to highlight the inextricable connection between the Eucharist and peace-making. Already as early as St. Augustine, we see the relation between unity and peace. Indeed, the Eucharist is a sacrament of peace because it is a sacrament of unity. ${ }^{17}$ Discussion of the Eucharist and the "common good" also has historical roots. In his commentary on 1 Corinthians 12:12-31, St. Thomas identifies Christ as the "common good of the entire universe." 18 If the common good of the universe is found in Christ, and "the whole Christ is found in the Eucharist" per the Council of Trent, then it follows that the Eucharist is the common good - the lasting peace - of all humankind. ${ }^{19}$

Pope Emeritus Benedict XVI, known for his devotion to the Sacred Liturgy, also had a profound Eucharistic theology rooted in both the horizontal and vertical dimensions of Christ's Body. Benedict sees Christ's sacrifice as the "living synthesis of the law;" ${ }^{20}$ Christ fulfills the Jewish 'Shema,' the command to love God with all might, soul, and strength (Deut. 6:4), and he fulfills the command to love one's neighbor as oneself (Mark 12:31). The sacrament of the Eucharist, as the memorial of Christ's passion, death, and resurrection, is therefore the apex of "Christ's love for God and love for our brothers and sisters." 21 The Eucharist, according to Benedict, is properly called 'peace',

"...for it is there that God does in fact come to meet us, that he sets us free, that, although we are debtors, guilty in his sight, he takes us in his arms, gives himself to us. And by leading us to himself, introducing us into the communion of his Body, by introducing us into the same sphere of his love, by feeding us with the same Bread, he also gives us to one another as brothers and sisters. The Eucharist is peace from the Lord."22

The recognition of Jesus in the Most Holy Sacrament of the Altar is a recognition of Jesus himself in all those who suffer. As Benedict writes, "Those who recognize Jesus in the Sacred Host, recognize Him their suffering brother or sister, in those

${ }^{17}$ Augustine of Hippo, In Joannis Evangelium, 26.13, trans. John Gibb, in Nicene and PostNicene Fathers, First Series, Vol. 7, ed. Philip Schaff. (Buffalo, NY: Christian Literature Publishing Co., 1888), ed. by Kevin Knight, New Advent, accessed October 4, 2017, http://www.newadvent.org/fathers/1701026.htm.

${ }^{18}$ Thomas Aquinas, On the First Epistle to the Corinthians, cap. 12, lec. 3, trans. by Fabian Larcher, O.P., Dominican House of Studies, accessed October 4, 2017, http://dhspriory.org/thomas/ $\underline{\text { SS1Cor.htm\#123. }}$.

${ }^{19}$ Peter A Kwasniewski, Resurgent in the Midst of Crisis (Tacoma, WA: Angelico Press, 2015), 193.

${ }^{20}$ Benedict XVI, Heart of the Christian Life: Thoughts on the Holy Mass (San Francisco, CA: Ignatius Press, 2010), 35.

${ }^{21}$ Benedict XVI, Heart of the Christian Life, 35.

${ }^{22}$ Benedict XVI, Heart of the Christian Life, 117. 
who hunger and thirst, who are strangers, naked, sick or in prison; and they are attentive to every person, they work in practice for all who are in need." 23

Thus, we see that in Benedict's theology, the Mass is the source of the Christian social vision. In his post-synodal apostolic exhortation, Sacramentum caritatis, Benedict sees the Eucharist as the source of all peace-making. Our inability to "possess Christ just for [ourselves]" results in our realization that we "can belong to him only in union with all those who have become, or who will become, his own." 24 Citing Pope Paul VI, who famously coined the phrase, "If you want peace, work for justice," 25 Benedict highlights the need of the Christian, nourished by the Eucharist, to have a "determination to transform unjust structures and to restore respect for the dignity of all men and women, created in God's image and likeness." 26 In closing, we see how the Eucharist provides a channel of peace, communicating God's salvific Shalom to humankind. God's gift of peace is the impetus for those baptized Christians working towards peace in the world today. Along with the many tools used for 'peace-making' today, we should consider the place of the Eucharist among them, and meditate upon the words of our Lord, who said "... apart from me, you can do nothing" (John 15:5).

\section{Bibliography}

Arrupe, Pedro. “The Eucharist and Hunger, ” Justice with Faith Today: Selected Letters and Addresses - II, ed. Jerome Aixala. St. Louis, MO: The Institute of Jesuit Sources, 1980.

Athanasius of Alexandria. De Incarnatione verbi, Translated by Archibald Robertson. From Nicene and Post-Nicene Fathers, Second Series, Vol. 4. Edited by Philip Schaff and Henry Wace. Buffalo, NY: Christian Literature Publishing Co., 1892. Edited by Kevin Knight. New Advent. Accessed October 1, 2017. http://www.newadvent.org/fathers/2802.htm.

${ }^{23}$ Benedict XVI, Homily for the Solemn Mass of Corpus Christi (2005), ed. Alcuin Reid, From Eucharistic Adoration to Evangelization (Bloomsbury Publishing, 2012), 221.

${ }^{24}$ Benedict XVI, Post-Synodal Apostolic Exhortation Sacramentum caritatis (22 February 2007) §89, The Holy See, accessed October 4, 2017, http://w2.vatican.va/content/benedict-xvi/en/ apost_exhortations/documents/hf_ben-xvi_exh_2 0070222 sacramentum-caritatis.html.

${ }^{25}$ Paul VI, Message for the Celebration of the Day of Peace (1 January 1972), The Holy See, accessed October 4, 2017, https://w2.vatican.va/content/paul-vi/en/messages/peace/documents /hf_p-vi_mes_19711208_v-world-day-for-peace.html

${ }^{26}$ Paul VI, Message for the Celebration of the Day of Peace. 
Augustine of Hippo. In Joannis Evangelium, Translated by John Gibb. From Nicene and Post-Nicene Fathers, First Series, Vol. 7. Edited by Philip Schaff. Buffalo, NY: Christian Literature Publishing Co., 1888. Edited by Kevin Knight. New Advent. Accessed October 4, 2017. http://www.new advent.org/fathers/1701026.htm.

Benedict XVI. Post-Synodal Apostolic Exhortation Sacramentum caritatis (22 February 2007). The Holy See. Accessed October 4, 2017. http://w2.vatican.va/content/benedict-Xvi/en/apost_exhortations/documents/hf_benxvi_exh_20070222_sacramentum-caritatis.html.

- Heart of the Christian Life: Thoughts on the Holy Mass. San Francisco, CA: Ignatius Press, 2010.

- Homily for the Solemn Mass of Corpus Christi (2005), ed. Alcuin Reid, From Eucharistic Adoration to Evangelization. Bloomsbury Publishing, 2012.

Catechism of the Catholic Church. 2nd ed. Washington, DC: United States Catholic Conference, 2000.

Kwasniewski, Peter A. Resurgent in the Midst of Crisis. Tacoma, WA: Angelico Press, 2015.

Paul VI. Message for the Celebration of the Day of Peace (1 January 1972). The Holy See. Accessed October 4, 2017. https://w2.vatican.va/content/paulvi/en/messages/peace/documents/hf_p-vi_mes_19711208_v-world-dayfor-peace.html.

Ratzinger, Joseph. God Is Near Us. San Francisco, CA: Ignatius Press, 2003.

Reid, Alcuin. From Eucharistic Adoration to Evangelization. Bloomsbury Publishing, London, 2012.

Thomas Aquinas. On the First Epistle to the Corinthians, Translated by Fabian Larcher, O.P. Dominican House of Studies. Accessed October 4, 2017. http://dhspriory.org/thomas/SS1Cor.htm\#123.

Schmemann, Alexander. For The Life of the World. Crestwood, NY: St. Vladimir's Seminary Press, 2004.

Vatican Council II. Dogmatic Constitution on the Church Lumen gentium, (21 November 1964). The Holy See. Accessed October 4, 2017. http://www. vatican.va/archive/hist_councils/ii_vatican_council/documents/vat-

ii const 19641121 lumen-gentium en.html. 